\title{
References
}

Løvborg, L. 1967: A portable $\gamma$-spectrometer for field use. Danish Atomic Energy Commission, Risø Report 168, 36 pp.

Løvborg, L., Kunzendorf, H. \& Hansen, J. 1968: Use of field gamma-spectrometry in the exploration of uranium and thorium deposits in South Greenland. IAEA symposium on the use of nuclear technique in the prospecting and development of mineral resources, Buenos Aires, 1968. Nuclear techniques and mineral resources, 197-211. Vienna: Int. Atomic Energy Agency.

Løvborg, L., Wollenberg, H., Sørensen, P. \& Hansen, J. (in press): Field determination of uranium and thorium by gamma-ray spectrometry, exemplified by measurements in the Ilimaussaq alkaline intrusion, South Greenland. Econ. Geol.

Sørensen, H., Hansen, J. \& Bondesen, E. 1969 : Preliminary account of the geology of the Kvanefjeld area of the Ilímaussaq intrusion, South Greenland. Rapp. Gronlands geol. Unders. 18, $40 \mathrm{pp}$.

\section{DETAILED MAPPING IN THE SOUTHERN PART OF THE ILÍMAUSSAQ INTRUSION (KANGERDLUARSSUK FJORD)}

\begin{abstract}
A. Demin
Detailed mapping at a scale of $1: 10000$ of an area around the head of the Kangerdluarssuk fjord in the southern half of the Ilimaussaq intrusion was made. The purpose of this was to map accurately the relations of naujaite inclusions in the lujavrites. During the work it became clear that a detailed study of the transitions between the lujavrites and kakortokites was of much greater importance. The reader is referred to Ferguson (1970, p. 338) for a summary of the previous ideas about the origin of the lujavrites.

The field observations of last summer showed that the green aegirine lujavrites and the black arfvedsonite lujavrites belong to different phases of intrusion (cf. Sørensen, 1962). The green lujavrites form the upper part of a unit which is continuous with the kakortokites. Between the green lujavrites and the kakortokites there is a sequence of transitional rocks (cf. Brooks \& Bohse, 1969). It consists of finegrained bands, black, white and red in colour, reminiscent of the colour variation in the banded kakortokites more to the south. The uppermost red band of the transitional sequence is always underlain by a $1 \mathrm{~m}$ thick layer of green lujavrite and grades over a distance of $4 \mathrm{~m}$ into the overlying lujavrites. The contacts between the bands are parallel and in general gradual, although locally the upper red bands have sharp contacts.

The black lujavrites crystallised from a late magma phase which was injected, possibly due to tectonic movements, while the crystallisation of the green lujavrites was still in progress. In the lower levels the newly injected magma consolidated by a
\end{abstract}


process of segregation producing bands and irregular patches, black, green, white and red in colour, corresponding to concentrations of arfvedsonite, aegirine, feldspar and eudialyte respectively.

Apart from the green bands which are identical to green lujavrite, these segregational rocks lack the lamination and fissility which is so characteristic of the lujavrites. In the lowermost levels the material of the segregation zone has intruded green lujavrite generally parallel to its fissility. Upwards these rocks form apophyses into each other with conformable and sharp boundaries. In the higher levels of the segregation zone black lujavrites occur.

The contacts of the lujavrites and their roof rocks of naujaite are everywhere characterised by development of irregular bands, veins and pegmatites. The contact rocks are characterised by mineralisation of thorium, uranium and rare earth metals occurring in steenstrupine. Pyrochlore, neptunite and other minerals have been found.

Future field and laboratory work is necessary to substantiate the field observations and to define mor 2 closely the rock types of the transitional and segregational series. The mineralisation of rare metals should be further investigated for economic and mineralogical purposes.

\section{References}

Brooks, C. K. \& Bohse, H. 1969: New field investigations of the Ilimaussaq kakortokite. Rapp. Grønlands geol. Unders. 19, 41-42.

Ferguson, J. 1970: The differentiation of agpaitic magmas: The Ilímaussaq intrusion, South Greenland. Can. Miner. 10, 335-349.

Sørensen, H. 1962: On the occurrence of steenstrupine in the Ilímaussaq massif, Southwest Greenland. Bull. Gronlands geol. Unders. 32 (also Meddr Gronland 167, 1) 251 pp.

\section{MINERALISED ULTRAMAFIC ROCKS IN SOUTH GREENLAND}

\section{H. K. Schönwandt}

In 1960 several mineralised ultramafic boulders with a remarkable content of $\mathrm{Pt}$ were found by M. Lorétan in the neighbourhood of Sarqâ fjord in the Nanortalik district, South Greenland. This stimulated interest in a closer examination of the mafic and ultramafic rocks of South Greenland and in 1962 and 1963 J. P. Berrangé mapped three ultramafic plutons in the district. One of the plutons is situated close to the place where Lorétan had found the mineralised ultramafic boulders. Berrangé (in press) concluded that the plutons had a greater affinity to the appinitic suite of 